\title{
The situation of curriculums of faculty of pharmacies in Turkey
}

\author{
Mehmet Barlas UZUN, Gizem GÜLPINAR, Gülbin ÖZÇELIKKAY
}

\begin{abstract}
The aim of this study is to compare pharmacy faculties in Turkey in terms of their curriculums, within itself and with some of the European countries, compare the distribution of pharmacist employment and student/staff/pharmacists distributions with EU (European Union). With this information, this study intends to provide information to students, academicians, foreign students and foreign academicians, accreditation boards and interested parties about pharmacy education in Turkey.

Internationalization of higher education increased rapidly during the last decades. Both developed and developing country universities especially give importance to internationalization. With its young population, Turkey has a great potential for student and academic mobility to attract foreign students and improve its higher education.
\end{abstract}

After pharmacy education duration has been adopted to 5 years, 11 new faculties of pharmacy began providing education in Turkey, until 2013-2014 academic year. Disharmonization of curriculums may lead to restrict mobility of students between faculties of pharmacy in or out of the country.

In this study, 21 Turkish faculties of pharmacy's curriculums have been examined and compared with the Pharmacy Education in Europe (Pharmine)'s classification. When comparing faculties of pharmacy's curriculums with each other; there have been a negative correlation between CHEMSCI (chemical sciences) and MEDISCI (medicinal and therapeutical sciences) course groups and some of the course groups not distributed normally.

To benefit from internationalization of higher education, faculty of pharmacies in Turkey should be accredited at national and international level. Design of the curriculum is one of the main parts of accreditation, therefore it should be prepared carefully by bearing in mind the other pharmacy curriculums in and out of the country.

Keywords: Education, pharmacy, pharmacy education, Europe, Turkey
Mehmet Barlas Uzun, Gizem Gülpınar, Gülbin Özçelikay

Ankara University Faculty of Pharmacy, Department of Pharmacy

Management, Ankara, Turkey.

Corresponding Author:

Mehmet Barlas Uzun

e-mail: mehmetbarlasuzun@gmail.com

Submitted/Gönderilme:30.04.2015 Revised/Düzeltme:21.06.2016ve20.09.2016 Accepted / Kabul: 21.09.2016

\section{INTRODUCTION}

Internationalization of higher education rapidly increased during the last decades. Especially information technology, using English as lingua franca for scientific communication and research collaborations speed up the internationalization process of higher education. With internationalization universities can enhance their curricula, gain prestige and exchange information with international partners. Students also, can access to higher education where their countries cannot meet the demand, provide international and crosscultural perspectives and have professional mobility [1].

At first, EU promoted internalization with programs like Erasmus that provide large number of students to complete a part of their education outside their own country. In 
1999 Bologna declaration was signed by the ministers of education from 29 European countries. Bologna process aims to harmonize entire academic system of EU for compatible degree structures, transferable credits and equal academic qualifications. Bologna process expanded to 47 EU-member or non-EU member countries in 2010. Turkey as a full member of Bologna process since 2001, began to use European Credit Transfer System (ECTS) after 2005-2006 academic year. As an ongoing process, Higher Education Institution of Turkey, worked on comprehensibility of diplomas and degrees, quality assurance in higher education and student and academic mobility[1-3].

In addition, EU accepted 2005/36/EC directive on recognition of professional qualifications to improve free movement of people and services in EU, in 2005. According to directive, "evidence of formal qualifications as a pharmacist shall attest to training of at least five years' duration, including at least: four years of full-time theoretical and practical training at a university or at a higher institute of a level recognized as equivalent, or under the supervision of a university; sixmonth traineeship in a pharmacy which is open to the public or in a hospital, under the supervision of that hospital's pharmaceutical department" [4].

In Turkey, the studies about the harmonization of faculties of pharmacy with EU members were started with the permission of free movement agreement of Turkish Health Staff in the beginning of 1990s. It is based up on the Direction of 85/434/ ECC dated September, 161985 [5].

In 14 January 2005 with the judgement of Higher Education Institution of Turkey, 4-year pharmacy education was altered to 5 -year due to the EU directive 2005/36/EC. As stated in the directive, the first 4 year determined as core curriculum for professional education and last year reserved for graduation project, some elective courses and traineeship [6].

According to the teaching of pharmacy internship applications which entered into force on February 2, 2008, the article of "regulations on medicine, nursing, midwifery, pharmacy, dentistry, veterinary medicine and architecture education programs determined the minimum training conditions" edited again. Article number 8 of this regulation becomes "a pharmacist must complete a minimum 6 month mandatory traineeship under the control of pharmacist in public pharmacy or in hospital". This regulation has been implemented since 2008 [7].

To be successful in the regulation of higher education and as a part of this in Bologna process, quality assurance is a must. Pharmine also surveyed the quality assurance in European pharmacy education and training by a questionnaire based on International Pharmaceutical Federation (FIP) and Accreditation Council for Pharmacy Education guidelines. Also, in Turkey, National Pharmacy Accreditation Board (ECZAK) established in 2011 [8-10].

In this context, the aim of this study is to compare pharmacy faculties in Turkey in terms of their curriculums, among themselves and with some of the European countries, compare the distribution of pharmacist employment and student/staff/pharmacists distributions with EU. With this information, this study intends to provide information to students, academicians, foreign students and foreign academicians, accreditation boards and interested parties about pharmacy education in Turkey.

\section{MATERIAL AND METHODS}

In this study, 21 faculty of pharmacies' in Turkey compared with Pharmine's classification in terms of their curriculums (except for projects and training courses). The faculties included in this study have accepted students on the education year 2013-2014 (Erzincan and Yüzüncü Yıl Universities Faculties of Pharmacy was excluded from study because they didn't have a proper curriculum at that time). Data collection was conducted between the years of 2013-2014.

The Pharmine consortium, created in 2008 and consists of 50 universities from EU member states and other European countries which are members of European Association of Faculties of Pharmacy (EAFP). The consortium also collaborates with Pharmaceutical Group of the European Union (PGEU), European Association of Hospital Pharmacists (EAHP), European Industrial Pharmacists' Group (EIPG) and European Pharmacy Students' Association (EPSA). The consortium created to examine pharmacy practice in EU in different setting: community, hospital, industry and other sector. The consortium also interests and examines pharmacy education, courses and traineeship based on statistical analysis.

Pharmine classifies the courses of pharmacy education courses in 7 main areas, which are biological sciences (BIOSCI), pharmaceutical technology (PHARMTECH), medicinal and therapeutical sciences (MEDISCI), law and social sciences (LAWSOC), chemical sciences (CHEMSCI), generic competencies (GENERIC) and physical and mathematical sciences (PHSYMATH) [11, 12].

Detailed classification given in the following table (Table 1); 
Table 1. Lectures grouping

\begin{tabular}{|c|c|}
\hline Biological Sciences "BIOLSCI" & Pharmaceutical Technology "PHARMTECH" \\
\hline a. Foundation biology & a. Galenic formulation / pharmaceutics \\
\hline b. Cell biology & b. Drug disposition and metabolism (ADME) / pharmacokinetics \\
\hline c. Botany & c. Novel drug delivery systems \\
\hline d. Mycology & d. Drug design \\
\hline e. Biochemistry & e. Pharmaceutical R\&D \\
\hline f. Molecular biology & f. Drug production \\
\hline g. Microbiology & g. Quality assurance in production \\
\hline i. Nutrition, non-pharmacological treatment & h. Drug/new chemical entity registration and regularization \\
\hline j. Hematology & 1. Cosmetics \\
\hline k. Immunology & \\
\hline 1. Parasitology & \\
\hline
\end{tabular}

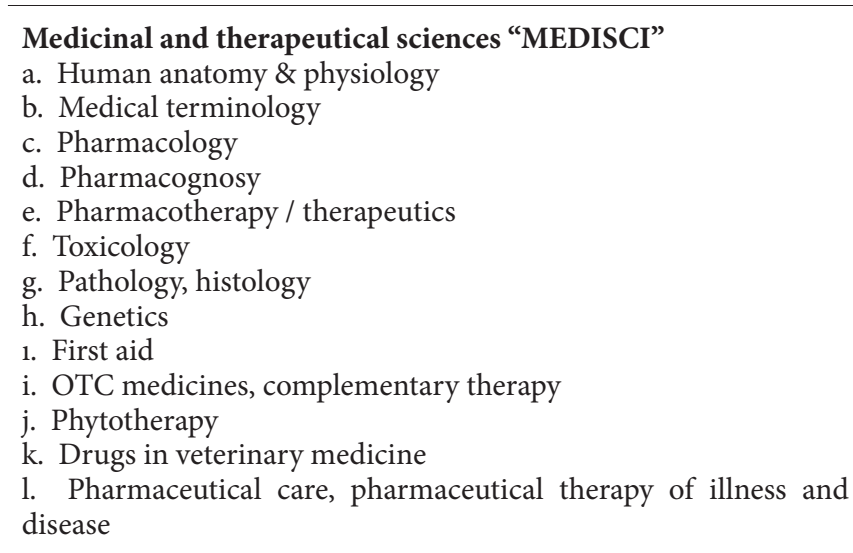
disease

\section{Law and social sciences "LAWSOC"}

a. Legislation, law relating to pharmacy

b. Social sciences

d. Professional ethics

e. Philosophy

f. Economics, financial affairs, book keeping, economic planning and management

g. Public health/health promotion

h. Quality management

i. Epidemiology of drug use (pharmaco-epidemiology)

j. Economics of drug use (pharmaco-economics)

k. History of pharmacy

1. Communication

\section{Chemical sciences "CHEMSCI"}

a. General, organic \& inorganic chemistry

b. Analytical chemistry

c. Pharmaceutical chemistry/pharmacopeial analysis

d. Medicinal physicochemistry / SAR / drug design

\section{Generic competences "GENERIC"}
a. General knowledge
b. Academic literacy
c. Languages
d. Practical skills

\section{Physical and Mathematical Sciences "PHYSMATH"}

a. Physics

b. Mathematics, pharmaceutical calculations

c. Statistics

Curriculum data were obtained from 21 faculties of pharmacy that accepted students in 2013-2014 academic year in Turkey. Erzincan and Yüzüncü Yll Universities pharmacy faculties was excluded from study because they didn't have a proper curriculum at that time. First courses and course hours taken from the internet addresses of the pharmacy faculties and then courses are classified according to Pharmine's classification. After calculating the total number of hours for each group, course hours converted into percent (Table 3).

Twenty one faculties of pharmacy data were shared by all researchers and each researcher examined and classified the courses according to Pharmine's classification. After that classified courses were cross checked between the researchers.

Statistical analysis was made according to the study that Pharmine conducted in 2011. Pharmacy education in Turkey and in Europe was compared in terms of Pharmine classification. The Kolmogorov-Simirnov (KS) test was used to examine whether a deviation of distribution from normality is occurred or not [12].

Pearson's correlation coefficient $(r)$ was used to investigate the relationship between the all course groups of Pharmine classification for pharmacy faculties in Turkey. For a correlation between variables $\mathrm{x}$ and $\mathrm{y}$, the formula for calculating the sample Pearson's correlation coefficient is given by ${ }^{13}$ where $x i$ and yi are the values of $\mathrm{x}$ and $\mathrm{y}$ for the ith individual.

$$
r=\frac{\sum_{i=1}^{n}\left(\left(x_{i}-\bar{x}\right)\left(y_{i}-\bar{y}\right)\right)}{\sqrt{\sum_{i=1}^{n}\left(x_{i}-\bar{x}\right)^{2} \sum_{i=1}^{n}\left(y_{i}-\bar{y}\right)^{2}}}
$$

Interpreting the size of a Correlation Coefficient was showed in Table 2 [13]. 
Table 2. Interpreting the size of a Correlation Coefficient

\begin{tabular}{ll}
\hline Size of Correlation & Interpretation \\
\hline .90 to $1.00(-.90-1.00)$ & $\begin{array}{l}\text { Very high positive (negative correla- } \\
\text { tion) }\end{array}$ \\
.70 to $.90(-.70-.90)$ & $\begin{array}{l}\text { High positive (negative) correlation } \\
.50 \text { to } .70(-.50-.70)\end{array}$ \\
$\begin{array}{l}\text { Moderate positive (negative) correla- } \\
\text { tion }\end{array}$ \\
.30 to $.50(-.30-.50)$ & $\begin{array}{l}\text { Low positive (negative) correlation } \\
.00 \text { to } .30(-.00-.30)\end{array}$ \\
\hline
\end{tabular}

The numbers of pharmacy employment, academic staff, pharmacy students and pharmacists in EU and Turkey compared in Table 5 and 6.

\section{RESULTS}

The schedule of theoretical and practical lectures was calculated as hour for each semester which has been approximately 14 weeks.

The classification of 21 faculties of pharmacy lectures are as in the following tables:

Table 3. Subject areas in \% in pharmacy faculties in Turkey

\begin{tabular}{|c|c|c|c|c|c|c|c|c|}
\hline Faculty & CHEMSCI & PHSYMATH & BIOLSCI & PHARMTECH & MEDISCI & LAWSOC & GENERIC & TOTAL \\
\hline \multicolumn{9}{|l|}{ Ağrı İbrahim Çeçen } \\
\hline University & 27.78 & 3.33 & 13.33 & 14.44 & 26.67 & 5.56 & 8.89 & 100 \\
\hline Anadolu University & 23.97 & 1.17 & 11.11 & 15.79 & 30.41 & 4.68 & 12.87 & 100 \\
\hline Ankara University & 24.46 & 3.26 & 15.76 & 15.76 & 17.39 & 2.72 & 20.65 & 100 \\
\hline Atatürk University & 26.37 & 3.3 & 13.19 & 14.29 & 29.67 & 4.4 & 8.78 & 100 \\
\hline Bezm-i Alem University & 17.3 & 5.4 & 11.89 & 14.05 & 32.43 & 3.78 & 15.15 & 100 \\
\hline Cumhuriyet University & 20.11 & 2.3 & 15.52 & 19.54 & 27.01 & 7.47 & 8.05 & 100 \\
\hline Dicle University & 27.69 & 3.08 & 13.85 & 12.31 & 26.66 & 6.15 & 10.26 & 100 \\
\hline Ege University & 22.87 & 4.26 & 10.11 & 15.96 & 23.94 & 6.91 & 15.95 & 100 \\
\hline Erciyes University & 23.37 & 14.67 & 3.26 & 15.22 & 29.89 & 4.89 & 8.7 & 100 \\
\hline Gazi Universirty & 21.98 & 3.29 & 14.84 & 15.38 & 25.82 & 4.4 & 14.29 & 100 \\
\hline Hacettepe University & 23.78 & 3.66 & 14.02 & 14.63 & 31.71 & 2.44 & 9.76 & 100 \\
\hline İnönü University & 24.13 & 3.44 & 13.8 & 13.8 & 29.31 & 4.02 & 11.5 & 100 \\
\hline İstanbul University & 23.75 & 6.25 & 15.62 & 13.75 & 22.5 & 8.13 & 10 & 100 \\
\hline \multicolumn{9}{|l|}{ Karadeniz Technical } \\
\hline University & 25 & 2.9 & 11.63 & 15.12 & 32.55 & 3.5 & 9.3 & 100 \\
\hline Kemerburgaz University & 19.1 & 5.06 & 12.36 & 5.62 & 34.27 & 15.17 & 8.42 & 100 \\
\hline Marmara University & 21.08 & 2.45 & 8.82 & 17.16 & 29.41 & 14.22 & 6.86 & 100 \\
\hline Medipol University & 25.72 & 2.29 & 12.57 & 13.71 & 25.71 & 2.86 & 17.14 & 100 \\
\hline Mersin University & 24.88 & 5.85 & 12.68 & 15.12 & 29.27 & 4.4 & 7.8 & 100 \\
\hline Trakya University & 20.86 & 3.68 & 15.34 & 14.72 & 31.9 & 4.9 & 8.6 & 100 \\
\hline Yeditepe University & 15.9 & 5.3 & 8.33 & 13.64 & 37.9 & 10.61 & 8.32 & 100 \\
\hline Yeniyüzyıl University & 18.42 & 2.3 & 9.54 & 13.82 & 23.35 & 23.67 & 8.9 & 100 \\
\hline Turkey & 22.49 & 4.13 & 12.1 & 14.47 & 28.23 & 7.56 & 11.02 & 100 \\
\hline
\end{tabular}


Table 4. Subject areas in \% statistical analysis

\begin{tabular}{|c|c|c|c|c|c|c|c|}
\hline & CHEMSCI & PHYSMATH & BIOLSCI & PHARMTECH & MEDISCI & LAWSOC & GENERIC \\
\hline Number & 21 & 21 & 21 & 21 & 21 & 21 & 21 \\
\hline Median & 23.75 & 3.33 & 12.68 & 16.63 & 29.31 & 4.89 & 9.30 \\
\hline \%10 Percentile & 17.52 & 2.29 & 8.43 & 12.58 & 22.67 & 2.75 & 7.85 \\
\hline$\% 90$ Percentile & 27.43 & 6.17 & 15.60 & 16.92 & 33.93 & 14.99 & 16.90 \\
\hline Mean & 22.79 & 4.15 & 12.27 & 14.47 & 28.47 & 6.90 & 10.96 \\
\hline Standard deviation & 3.26 & 2.74 & 3.02 & 2.52 & 4.56 & 5.18 & 3.66 \\
\hline Standard error & 0.712 & 0.598 & 0.660 & 0.549 & 0.994 & 1.130 & 0.799 \\
\hline \multicolumn{8}{|l|}{ KS normality test } \\
\hline KS distance & 0.142 & 0.235 & 0.132 & 0.276 & 0.142 & 0.224 & 0.243 \\
\hline$P$ value & $>0.10$ & 0.004 & $>0.10$ & 0.000 & $>0.10$ & 0.007 & 0.002 \\
\hline $\begin{array}{l}\text { Passed normality test } \\
(\text { alpha }=0.05) ?\end{array}$ & Yes & No & Yes & No & Yes & No & No \\
\hline$P$ value summary & ns & $* *$ & ns & ** & ns & $* *$ & $* *$ \\
\hline Skewness & -0.356 & 11.296 & 2.623 & 8.060 & 0.790 & 4.790 & 1.013 \\
\hline Kurtotsis & -0.498 & 3.013 & -1.377 & -1.889 & -0.349 & 2.122 & 1.316 \\
\hline Sum & 478.52 & 87.24 & 257.57 & 303.83 & 597.77 & 144.88 & 230.19 \\
\hline
\end{tabular}

ns: not significant

${ }^{* *}: \mathrm{p}<0.01$

Course hours of all faculties in Turkey have been analyzed in terms of a normal distribution. It was seen that only Medisci and Chemsci course hours showed normal distribution.

Table 5. Turkey and EU pharmacists*

\begin{tabular}{lllllllllll}
\hline & $\begin{array}{l}\text { Population } \\
\text { (million) }\end{array}$ & $\begin{array}{l}\text { Community } \\
\text { Pharmacists }\end{array}$ & \% total & $\begin{array}{l}\text { Hospital } \\
\text { Pharmacists }\end{array}$ & \% total & $\begin{array}{l}\text { Industrial } \\
\text { Pharmacists }\end{array}$ & \% total & $\begin{array}{l}\text { Other } \\
\text { occupations }\end{array}$ & $\begin{array}{c}\% \text { total } \\
\text { Total } \\
\text { number of } \\
\text { pharmasits }\end{array}$ \\
\hline Turkey & 78.7 & 24406 & $\% 90.35$ & 1502 & $\% 5.56$ & 253 & $\% 0.94$ & 851 & $\% 3.16$ & 27012 \\
EU & 504.2 & 329491 & $\% 78.57$ & 24782 & $\% 5.91$ & 36749 & $\% 8.76$ & 28331 & $\% 6.76$ & 419353 \\
\hline
\end{tabular}

* 25 EU countries data were taken from Pharmine report. Turkey data were taken from Turkish Republic of Ministiry of Health reports [12, $14,15]$.

The distribution of pharmacy employment in Turkey and EU are given in Table 5.

Table 6. Turkey and EU Higher education institutions (HEI), staff and students*

\begin{tabular}{lllllll}
\hline & Number HEIs & Staff & Staff/HEI & Students & Students/Staff & Students/Pharmacists \\
\hline Turkey & 23 & 524 & 22.78 & 7693 & 14.68 & 0.285 \\
EU & 110 & 7870 & 71.55 & 15594 & 1.98 & 0.075 \\
\hline
\end{tabular}

* 25 EU countries data were taken from Pharmine report. Turkey data were taken from Turkish Republic of Ministiry of Health reports $[12,14,15]$.

The relationship between HEIs, academic staff, pharmacy students and pharmacists' distribution in EU and Turkey is given in Table 6. 
No correlation was found between the subject areas except for CHEMSCI and MEDISCI according to Pearson's correlation coefficient. Because of the fact that the plots are scattered the correlation between CHEMSCI and MEDISCI can be interpreted as low negative correlation as seen in Figure 1 $(\mathrm{r}=0.391)$.

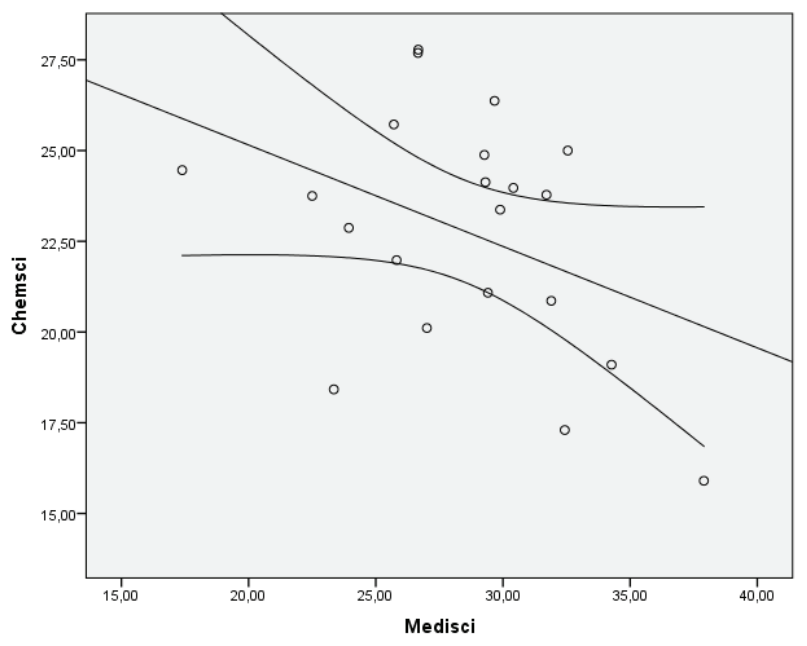

Figure 1. Linear expression of the correlation between CHEMSCI and MEDISCI in Turkey

\section{DISCUSSION}

Republic of Turkey Ministry of Health determined the number of employed pharmacists in Turkey as 31,300 in the 2023 vision. In this case, the number of pharmacies per 1000 population in Turkey is estimated to be 0.37 . If the current form of student recruitment for pharmacy faculties continues like that, approximately 9.000 pharmacists will be oversupply. Number of student pharmacists per pharmacists in Turkey is far above the European average (Table 3) and this reveals the situation in a concrete way in.[14].

According to a survey conducted by French Council of Pharmacists, there will be a pharmacist shortage in many countries in Europe. In this case, many pharmacy graduates will also have the opportunity to benefit the main aim of the Bologna Process; occupational mobility. As a shareholder of the Bologna process, Turkey should benefit from this mobility $[16,17]$.

One of the aims of the Bologna process is to harmonize higher education systems and make them comparable while preserving their unique differences. Pharmacy education have been studied for most of EU countries in Pharmine project to achieve this aim $[2,3,16]$.
When the course groups examined in Turkey (Table 3), it was observed that physmath, pharmtech, lawsoc and generic were not distributed normally between faculties. According to International Pharmaceutical Federation (FIP) and Accreditation Council for Pharmacy Education (ACPE) guidelines, curriculum is stated as one of the main criterias for assessing the quality of pharmacy education. While only generic group showed a deviation from the normal distribution between EU countries in Pharmine project, the deviation observed in many groups in Turkey reveals the differences between the faculty curriculums (Table 4). These differences may limit the mobility of students and graduates. Therefore, it is important to harmonize the pharmacy education $[2,9,12]$.

When considering the correlation between course groups in Turkey, a negative correlation was observed between the CHEMSCI and MEDISCI as well as in Pharmine (Figure 1). While the CHEMSCI+PHARMTECH/MEDISCI $=0.38$ in Ireland where the number of the hospital pharmacists is nearly twice as industrial pharmacists, this ratio is 3.63 in Denmark where the number of the industrial pharmacists is about 4.5 times of the hospital pharmacists. In Turkey, number of the hospital pharmacists is 6 times the industrial pharmacists and CHEMSCI+PHARMTECH/MEDISCI rate is 1.31. These numbers show that, when the number of the hospital pharmacists and industrial pharmacist considered, the course hours within the context of MEDISCI is insufficient in Turkey [12].

In the close future, if we do not take precautions, the excess of pharmacy graduates will be a problem in Turkey. Participating effectively to Bologna process might help Turkey in the solution of this problem.

Some of pharmacy faculties in Turkey, do not have adequate description about course contents in their web addresses, because of the fact that this study does not cover the course contents. The classification was made only by course titles.

Although the data obtained in this study is descriptive, it would constitute a prediction for the pharmacy curriculums in our country. Future studies might conduct detailed analysis for course contents and gather information through interviews with students and academic staff.

\section{CONCLUSION}

In a rapidly changing world, pharmacy practices and accordingly pharmacy education are changing rapidly. 
In Turkey with the newly opened faculties of pharmacies and new regulations, pharmacy education has undergone serious changes. In this study we try to make a projection of pharmacy education in Turkey. To understand the impact of Bologna process on pharmacy education in Turkey, more detailed studies are need to be conducted.

\section{ACKNOWLEDGEMENTS}

The authors thank all faculties of pharmacy administrations in Turkey who lent their assistance during the study.

\section{Türkiye'deki Eczacılık Fakültelerinin Müfredatlarının Değerlendirilmesi}

\section{ÖZ}

$\mathrm{Bu}$ çalışmanın amacı, Türkiyedeki eczacılık fakültelerinin müfredatlarını, Türkiyedeki eczacılık istihdamını ve öğrenci/ akademisyen/eczacı dağılımını kendi içinde ve bazı AB (Avrupa Birliği) ülkeleri ile karşılaştırarak, öğrenciler, akademisyenler, akreditasyon kurumları ve ilgili kuruluşlara Türkiye'deki eczacılık eğitim hakkında bilgi sağlamaktır.

Son yıllarda eğitimin uluslararasılaşması hızla artmıştır. Hem gelişmiş hem de gelişmekte olan ülkeler, uluslararasılaşmaya özellikle önem vermektedir. Genç nüfusuyla Türkiye, öğrenci ve akademisyen hareketliliği için büyük potansiyele sahiptir.

Eczacılık eğitimi 5 yıla çıktıktan sonra, Türkiye’de 2013-2014 yılına kadar 11 yeni eczacılık fakültesi eğitime başlamıștır.
Müfredatlar arasındaki uyumsuzluk, yüksek öğretim hareketliliğini yurtiçi ve yurtdışında Türkiye için kısıtlayabilir.

Bu çalışmada, Türkiye'de yer alan 21 eczacılık fakültesinin müfredatları, Pharmine sınıflandırılmasına göre incelenmiştir. Eczacılık fakültelerinin müfredatları karşılaştırıldığında kimya grubu (CHEMSCI) dersleri ile tıp/tedavi grubu (MEDISCI) dersleri arasında negatif bir korelasyon bulunmuş ve bazı ders gruplarının fakülteler arasında normal dağılmadığı gözlenmiștir.

Yüksek öğretimin uluslararasılaşmasından faydalanmak için Türkiye'deki eczacılık fakülteleri, ulusal ve uluslararası düzeyde akredite olmalıdır. Müfredatın dizaynı, akreditasyonun temel inceleme alanlarından biri olduğundan, müfredat ülke içindeki ve dışındaki eczacılık fakülteleri göz önüne alınarak hazırlanmalıdır.

Anahtar kelimeler: Eğitim, eczacılık, eczacılık eğitimi, Avrupa, Türkiye

\section{REFERENCES}

1. Altbach PG, Knight J. The internationalization of higher education: motivations and realities. J Stud Int Educ 2007; 11: 290-305.

2. Sağlam M, Özüdoğru F, Çıray F. Avrupa birliği eğitim politikaları ve türk eğitim sistemine etkileri. Yüzüncü Yıl Üniversitesi Eğitim Fakültesi Derg 2011; 8: 87-109.

3. Özkan SA, Esatoğlu AE. Bologna süreci ve eczacılık eğitimine etkileri. Meslek İçi Sürekli Eğitim Derg 2014; 33-34: 14-22.

4. Directive 2005/36/EC of the european parliament and of the council. Available in: PDF Document [http://eurlex.europa.eu/LEXUriServ/LexUriServ. do?uri=OJ:L:2005:255:0022:0142:EN:PDF; Accessed April 6, 2014].

5. Council decision of 16 September 1985 setting up an advisory committee on pharmaceutical training. Available in: PDF Document [http://eur-lex.europa.eu/legal-content/EN/ TXT/?uri=CELEX:31998D1114(03); Accessed May 2, 2014].

6. General Meeting Decision of Higher Education Institution of Turkey, 14.01.2005.

7. Doktorluk, hemşirelik, ebelik, diş hekimliği, veterinerlik, eczacılık ve mimarlık eğitim programlarının asgari eğitim koşullarının belirlenmesine dair yönetmelik. T.C. Resmi gazete, 26775, 02.02.2008.

8. "Realising the European Higher Education Area" Communiqué of the Conference of Ministers responsible for Higher Education in Berlin on 19 September 2003. Available in: PDF Document [http://www.enqa.eu/wpcontent/uploads/2013/03/BerlinCommunique1.pdf; Accessed February 9, 2016].

9. Morias JAG, Cavaco AM, Rombaut B, Rouse MJ, Atkinson J. Quality assurance in european pharmacy education and training. Phar Pract (Granada) 2011; 9: 195-9.

10. Pharmacy Accreditation Board. Internet page. Available in: PDF Document [https://www.acpe-accredit.org/; Accessed: February 7, 2016].

11. Higher Education Institution of Turkey quota manual. Accessed, January 12, 2015.

12. Atkinson J, Rombaut B. The 2011 Pharmine report on pharmacy and pharmacy education in the European Union. Phar Pract (Granada) 2011; 9: 169-87.

13. Mukaka MM. Statistics Corner: A guide to appropriate use of Correlation coefficient in medical research. Malawi Med J 2012; 24: 69-71.

14. Turkish Republic of Ministiry of Health. 2023 Health Manpower Goals and Health Education. Available in: PDF Document [https://sgb.saglik.gov.tr/content/ files/2016WEBSITESIREVIZYON/stratejik_plan_ing_ic.pdf; Accessed: January 24, 2016].

15. Turkish Republic of Ministiry of Health. Health Education and Health Manpower in Turkey Status Report 2014. Available in: PDF Document [Accessed: June, 15, 2016]

16. Atkinson J, Rombaut B. The Pharmine paradigm-matching the supply of pharmacy education and training demands. Eur Ind Pharm 2010; 6: 4-7.

17. European Observatory on Health Systems and Policies. Health professionals mobility and health systems in Europe. Available in: PDF Document [http://apps.who.int/iris/ bitstream/10665/170421/1/Health-Professional-MobilityHealth-Systems.pdf; Accessed: February 14, 2016]. 